\title{
PENGARUH KARAKTER INDIVIDU DAN TRADISI TERHADAP KEPATUHAN MENGONSUMSI TABLET ZAT BESI (FE) PADA IBU HAMIL DI WILAYAHPESISIRKABUPATEN BUTON UTARA SULAWESI TENGGARA
}

\author{
Irma ${ }^{1}$ Wa ode Salma ${ }^{2}$ Harleli $^{3}$ \\ ${ }^{123}$ Fakultas Kesehatan Masyarakat, Universitas Haluoleo, Kendari \\ irmankedtrop15@gmail.com ${ }^{1}$ waode.salma@uho.ac.id²harleli@gmail.com ${ }^{3}$
}

\begin{abstract}
Abstrak
Kepatuhan mengonsumsi tablet besi adalah meminum tablet Fe sesuai dengan dianjurkan. Penelitian ini bertujuan untuk mengetahui hubungan antara faktor tradisi dan pendidikan dengan kepatuhan mengonsumsi tablet besi (Fe) pada ibu hamil di wilayah kerja Puskesmas Waode Buri Kecamatan Kulisusu Utara Kabupaten Buton Utara tahun 2018. Jenis penelitian yang digunakan dalam penelitian ini adalah penelitian kuantitatif denganmenggunakanpendekatancross sectional study. Populasi dalam penelitian ini adalah seluruh ibuhamil yang terdaftar dan ada di wilayah kerja Puskesmas Waode Buri Kecamatan Kulisusu Utara Kabupaten Buton Utara yang berjumlah 42 orang dengan teknik pengambilan sampel adalah total sampling. Instrumen penelitian yang digunakan adalah lembar kuesioner sedangkan analisis data yang digunakan adalah uji Chi Square pada taraf kepercayaan $95 \%(\alpha=0,05)$. Hasil penelitian menunjukkan bahwa varibel umur $(\rho=0,0082)$, pendidikan $(\rho=$ $0,006)$ dan tradisi $(\rho=0,013)$ memiliki hubungan dengan kepatuhan mengonsumsi tablet besi $(\mathrm{Fe})$. Semua variabel bebas mempunyai hubungan dengan varibel terikat.
\end{abstract}

Kata Kunci: karakter individu;tradisi; konsumsi tablet besi (Fe); ibu hamil

\begin{abstract}
Compliance with consuming iron tablets is taking Fe tablets according to the recommended. This study aims to determine the relationship between tradition factors and education with adherence to consumption of iron (Fe) tablets in pregnant women in the working area of Waode Buri Community Health Center, North Kulisusu Subdistrict, and North Buton District in 2018. The type of research used in this study is quantitative research using an approach cross sectional study. The population in this study was all pregnant women who were registered and in the working area of Waode Buri Community Health Center, North Kulisusu Subdistrict, North Buton Regency, which consisted of 42 people with total sampling technique.The research instrument used was questionnaire while the data analysis used was Chi Square test at 95\% confidence level $(\alpha=0.05)$.The results showed that variables of age $(\rho=0.0082)$, education $(\rho=0.006)$ and tradition $(\rho=0.013)$ had a relationship with adherence to consuming iron tablets $(\mathrm{Fe})$. All independent variables have a relationship with the dependent variable.
\end{abstract}

Keywords: individual characters; tradition; consuming iron (Fe) tablets; pregnant mother 


\section{PENDAHULUAN}

Zat besi merupakan mikro elemen esensial bagi tubuh yang diperlukan dalam sintesa hemoglobin.Zat besi ( $\mathrm{Fe}$ ) juga merupakan mineral mikro yang paling banyak ditemukan dalam tubuh yaitu sekitar 3-5 gram di dalam tubuh manusia dewasa. Konsumsi tablet $\mathrm{Fe}$ sangat berkaitan dengan kadar hemoglobin pada ibu hamil ${ }^{1,2}$.

World Health Organization (WHO) melaporkan bahwa sampai saat ini angka kematian ibu masih sangat tinggi. Sekitar 830 wanita meninggal akibat komplikasi terkait kehamilan atau persalinan di seluruh dunia setiap hari.Salah satu komplikasi kehamilan yang sering memberi kontribusi pada angka morbiditas dan mortalitas ibu dengan kehamilan dan persalinan adalah anemia zat besi.Pada tahun 2015, sekitar 303.000 wanita meninggal selama dan setelah kehamilan dan persalinan.

Angka kematian ibu dan anak yang terjadi diseluruh dunia masih sangat tinggi.Angka kematian ibu di negara berkembang pada tahun 2015 menurut data yang dirilis WHO pada tahun 2017 adalah 239 per 100.000 kelahiran hidup dibandingkan 12 per 100.000 kelahiran hidup di negara maju ${ }^{3}$.

Faktor tradisi atau kebiasaan dalam hal ini kebiasaan makan pada saat hamil baik dalam bentuk porsi makan, pantang terhadap makanan tertentu seperti ikan dapat mempengaruhi asupan gizi khususnya gizi besi.lkan sebagai salah satu sumber makanan yang mengandung zat bezi. Berdasarkan hasil studi pendahuluan di lapangan (di wilayah kerja Puskesmas Waode Buri) dari 10 orang ibu hamil yang menjadi responden, sebanyak 9 orang $(90 \%)$ memiliki kebiasaan pantang makan ikan pada saat hamil dengan alasan yang kurang rasional seperti akan amis pada saat melahirkan dan bayi yang dilahirkan akan mengalami gangguan kulit misalnya gatal - gatal. Selain itu dari 10 orang yang menjadi responden pada studi pendahuluan ini ditemukan bahwa sebanyak 7 orang (70\%) mengurangi porsi makannya saat hamil.Faktor pendidikan sangat berpengaruh terhadap kemampuan seseorang dalam memahami sebuah informasi untuk menentukan sikap dan perilakunya termasuk dalam memutuskan hal-hal yang berkaitan dengan kesehatan.

Menurut penelitian yang pernah dilakukan di Wilayah Kerja Puskesmas Mokoau, Kota Kendari menemukan bahwa $79,4 \%$ responden dengan tingkat pendidikan tinggi akan memanfaatkan pelayanan kesehatan dengan baik termasuk mengonsumsi tablet Fe dan hanya 20,6\% responden yang tidak melaksanakan pelayanan kesehatan dengan baik. Hal ini menunjukkan bahwa tingkat pendidikan merupakan salah satu karakter individu yang cukup penting dalam menentukan sikap dari seseorang ${ }^{4}$.

Menurut WHO kejadian anemia sebanyak 2,3 miliar dan $50 \%$ dari kejadian anemia disebabkan oleh Anemia Defisiensi Besi (ADB), dan sekitar 75\% kejadian anemia di dunia terjadi pada ibu dan anak - anak. Sementara untuk kasus anemia di Asia mencapai 202 juta penderita dan sekitar 41,8\% adalah ibu hamil dan hampir $60 \%$ anak - anak ${ }^{3}$.

Menurut data yang diperoleh dari Dinas Kesehatan Provinsi Sulawesi Tenggara terdapat 683 kasus anemia zat besi untuk tahun 2017 dan dari jumlah tersebut sebesar $67,3 \%$ adalah ibu hamil dan sisanya adalah anak-anak dan usia remaja terutamaremaja wanita yang memasuki fase menarka sedangkan kasus anemia untuk Buton Utara pada tahun 2017 sebesar 108 kasus dan dari jumlah tersebut sebanyak 66 orang $(61,1 \%)$ merupakan ibu hamil dan sisanya adalah anak-anak, remaja dan lansia 5 .

Pemberian tablet Fe pada ibu hamil banyak mengalami kegagalan oleh karena berbagai faktor salah satunya adalah ketidakpatuhan pasien dalam meminum tablet Fe. Banyak hal yang dapat mempengaruhi kepatuhan ibu hamil dalam mengonsumsi atau meminum tablet besi ( $\mathrm{Fe}$ ) antara lain pengetahuan dan sikap, kepercayaan, tradisi, orang penting sebagai referensi, sumber daya seperti ketersediaan tablet $\mathrm{Fe}$, tenaga kesehatan dan fasilitas kesehatan dan lain sebagainya ${ }^{6}$.

Angka Kematian Ibu (AKI) Provinsi Sulawesi Tenggara pada tahun 2016 masih mengalami peningkatan yaitu 149 per 100.000 kelahiran hidup dibandingkan dengan tahun 2015 hanya 131 per 100.000 kelahiran hidup. Kondisi ini tentu masih lebih tinggi di atas target MDG's tahun 2016 yaitu 105 per 100.000 kelahiran hidup. AKI Kabupaten Buton Utara pada tahun 2016 juga masih tinggi yaitu 233 per 100.000 kelahiran hidup.Sementara untuk Angka Kematian Bayi (AKB) di Sulawesi Tenggara per 1000 kelahiran hidup adalah 3, sedangkan Kabuten Buton Utara dengan AKB 4 per 1000 kelahiran hidup.Masih tingginya AKI dan AKB ini dipengaruhi oleh berbagai faktor diantaranya adalah komplikasi pada masa kehamilan dan waktu persalinan seperti kurang gizi dan anemia ${ }^{7}$.

Di PuskesmasWaode Buri pada tahun 2017 terdapat 122 ibuhamilyang memeriksakan kehamilannyadandidapatkan 9kasus $(7,73 \%)$ yang mengalami anemia dan jumlah ibu hamil pada tahun 2018 dari periode Januari sampai dengan Mei 2018 sebesar 42 ibu hamil dengan kasus anemia sebanyak 4 orang $(9,52 \%)$. Kejadian anemia pada 
ibu hamil yang terjadi di Puskesmas Waode Buri dipengaruhi oleh rendahnya cakupan pemberian tablet zat besi (Fe) yaitu $58,2 \%$ yang jauh dibawah target nasional yaitu $85 \%$. Rendahnya cakupan pemberian tablet besi (Fe) ini sebagai akibat dari kurangnya motivasi dan kepatuhan ibu hamil dalam mengonsumsi tablet besi (Fe) sehingga peneliti tertarik mengadakan penelitian tentang hubungan faktor tradisi dan pendidikan dengan kepatuhan mengonsumsi tablet besi (Fe) pada ibu hamil di wilayah kerja Puskesmas Waode Buri Kecamatan Kulisusu Utara Kabupaten Buton Utara tahun 2018.

\section{METODE}

Penelitian ini merupakan penelitian kuantitatif denganpendekatancross sectional study.Variabel bebas adalah tradisi/kebiasaan dan faktor pendidikan sedangkan variabel terikat yaitu kepatuhan mengonsumsi tablet besi. Variabel diobservasisekaliguspadawaktu yang sama ${ }^{8}$.
Pengambilansampeldalam penelitian dilakukan dengan salah satu dari teknik non random sampling yaitu dengan teknik total sampling dimana seluruh populasi yang memenuhi kriteria sampling penelitian diambil sebagai sampel yaitu sebanyak 42 orang ibu hamil.Alat dan bahan yang digunakan dalam penelitian ini adalah lember kuesioner ${ }^{8}$.

\section{HASIL DAN PEMBAHASAN}

Berdasarkan hasil survei dan analisis data dari 42 responden dalam penelitian ini ditemukan hasil penelitian yaitu:

\section{Karakteristik Responden}

\section{a. Umur}

Umur adalah satuan waktu yang mengukur waktu keberadaan suatu mahluk, baik hidup maupun mati, yang diukur sejak dia lahirhingga waktu umur dihitung.Distribusi responden menurut kelompok umur disajikan pada tabel 1.

Tabel 1.Distribusi responden menurut umur di wilayah kerja Puskesmas Waode Buri Kecamatan Kulisusu Utara Kabupaten Buton Utara tahun 2018

\begin{tabular}{ccc}
\hline Umur(Tahun) & Jumlah(n) & Persentase(\%) \\
\hline $15-20$ & 5 & 11,90 \\
$21-25$ & 10 & 23,80 \\
$26-30$ & 17 & 40,47 \\
$31-35$ & 3 & 7,14 \\
$36-40$ & 6 & 14,28 \\
\hline Total & 42 & 100 \\
\hline
\end{tabular}

Tabel 1 menunjukkan sebagian besar responden atau sebanyak $17(40,47 \%)$ responden berumur antara 26-30 tahun, hanya $3(7,1 \%)$ responden berumur $36-40$ tahun. Ini disebabkan rata - rata atau sebagian besar responden adalah merupakan umur produktif.
Pendidikan adalah usaha sadar dan berencana untuk mewujudkan suasana belajar dan proses pembelajaran agar peserta didik secara aktif mengembangkan potensi dirinya. Distribusi responden menurut pendidikan terakhir disajikan pada tabel 2.

\section{b. Tingkat Pendidikan}

Tabel 2. Distribusi responden menurut tingkat pendidikan di wilayah kerja Puskesmas Waode Buri Kecamatan Kulisusu Utara Kabupaten Buton Utara tahun 2018

\begin{tabular}{ccc}
\hline Tingkat pendidikan & Jumlah $(\mathrm{n})$ & Persentase(\%) \\
\hline SD & 5 & 11,90 \\
SMP & 10 & 23,80 \\
SMA & 17 & 40,50 \\
SDIII/Akademik & 3 & 7,10 \\
S1/Sarjana & 6 & 14,28 \\
S2/ Pasca Sarjana & 1 & 2,40 \\
\hline Total & 42 & 100
\end{tabular}




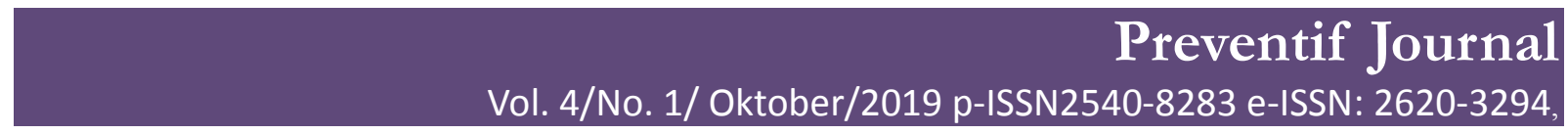

Tabel 2 menunjukkan bahwa sebanyak $17(40,5 \%)$ responden dengan tingkat pendidikan SMA/Sederajat, dan hanya $1(2,4 \%)$ responden dengan tingkat pendidikan S2/Pasca Sarjana.

\section{c. Pekerjaan}

Tabel 3.Distribusi responden menurut pekerjaan di wilayah kerja Puskesmas Waode Buri Kecamatan Kulisusu Utara Kabupaten Buton Utara tahun 2018

\begin{tabular}{ccc}
\hline Pekerjaan & Jumlah $(\mathrm{n})$ & Persentase $(\%)$ \\
\hline PNS & 8 & 19,04 \\
Pedagang & 2 & 4,80 \\
Honorer & 6 & 14,30 \\
Tani & 10 & 23,80 \\
IRT & 16 & 38,09 \\
\hline Total & 42 & 100 \\
\hline
\end{tabular}

Tabel 3 menunjukkan bahwa sebanyak 20 $(47,6 \%)$ responden adalah Ibu Rumah Tangga atau IRT, hanya $2(4,8 \%)$ responden bekerja sebagai Pedagang.

\section{Analisis Variabel Penelitian}

\section{a. Analisis Univariat}

\section{1) Pekerjaan}

Pekerjaan adalah kegiatan rutin yang dilakukan responden dan menghasilkan uang untuk menghidupi keluarganya.Dimana dalam penelitian ini pekerjaan responden bervariasi.Distribusi responden menurut tingkat pekerjaannya disajikan pada tabel 3.

Tabel 4. Distribusi responden berdasarkan pekerjaandi wilayah kerja Puskesmas Waode Buri Kecamatan Kulisusu Utara Kabupaten Buton Utara tahun 2018

\begin{tabular}{ccc}
\hline Pekerjaan & Jumlah $(\mathrm{n})$ & Persentase (\%) \\
\hline Ibu Rumah Tangga (IRT) & 16 & 38,09 \\
Pekerja aktif & 26 & 61,91 \\
\hline Jumlah & 42 & 100 \\
\hline
\end{tabular}

Tabel 4 menunjukkan bahwa sebagian besar yaitu sebanyak $26(61,91 \%)$ responden aktif dalam bekerja baik sebagai PNS, swasta maupun petani, hanya 16 (38,09\%) responden yang tidak bekerja secara aktif (hanya sebagai Ibu Rumah Tangga). Secara teori semakin tinggi tingkat kesibukan seseorang, maka semakin mengesampingkan halhal yang tidak terlalu mendesak atau penting.Dalam penelitian ini meskipun responden sebagian besar adalah orang yang bekerja secara aktif,akan tetapi masih banyak atau sebagian besar responden yang
Pekerjaan merupakan salah satu faktor yang dapat mempengaruhi pola pikir dan kematangan pengambilan keputusan bagi seseorang. Orang yang aktif bekerja memiliki komunikasi sosialdengan lingkungan tempat ia bekerja. Distribusi responden menurut faktor pekerjaan disajikan pada tabel 4.

Tabel 5.Distribusi responden berdasarkan pendidikan pada ibu hamil di wilayah kerja puskesmas Waode Buri Kecamatan Kulisusu Utara Kabupaten Buton Utara tahun 2018

\begin{tabular}{ccc}
\hline Pendidikan & Jumlah $(\mathrm{n})$ & Persentase (\%) \\
\hline Rendah & 15 & 35,71 \\
Tinggi & 27 & 64.29 \\
\hline Total & 42 & 100 \\
\hline
\end{tabular}




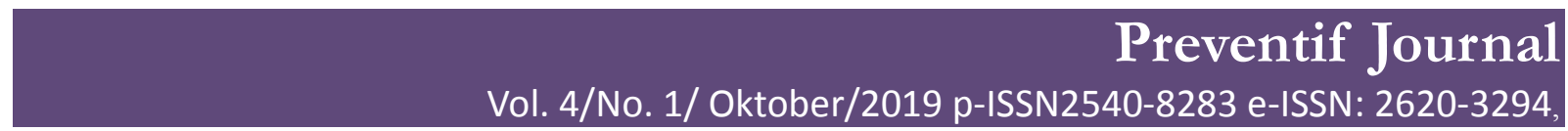

Tabel 5 menunjukkan bahwa sebagian besar yaitu sebanyak 27 (64,3\%) responden memiliki pendidikan dengan kategori tinggi, hanya 15 $(35,7 \%)$ responden memiliki pendidikan dengan kategori rendah.

Secara teori semakin tinggi pendidikan seseorang maka semakin baik dalam pengambilan keputusan terhadap sesuatu hal termasuk keputusan dalam dalam berperilaku atau bersikap terkait pelayanan kesehatan. Dalam penelitian ini meskipun responden sebagian besar memiliki tingkat pendidikan dengan kategori tinggi akan tetapi masih banyak atau sebagian besar responden yang memiliki kepatuhan dalam mengonsumsi tablet Fe yang tergolong rendah. Ini karena banyak faktor yang berpengaruh terhadap kepatuhan dari seseorang termasuk kepatuhan dalam mengonsumsi tablet Fe.

\section{3) Tradisi/kebiasaan}

Tradisi atau disebut juga dengan kebiasaan merupakan sesuatu yang sudah dilaksanakan sejak lama dan terus menjadi bagian dari kehiduap suatu kelompok masyarakat, seringkali dilakukan oleh suatu negara, kebudayaan, waktu, atau agama yang sama. Pengertian lain dari tradisi adalah segala sesuatu yang diwariskan atau disalurkan dari masa lalu ke masa saat ini atau sekarang6. Distribusi responden menurut faktor tradisi/kebiasaan disajikan pada tabel 6 .

Tabel 6.Distribusi responden berdasarkan tradisi/kebiasaan di wilayah kerja Puskesmas Waode Buri Kecamatan Kulisusu Utara Kabupaten Buton Utara tahun 2018

\begin{tabular}{ccc}
\hline Tradisi & Jumlah $(\mathrm{n})$ & Persentase $(\%)$ \\
\hline Kurang & 28 & 66,70 \\
Baik & 14 & 33,30 \\
\hline Jumlah & 42 & 100 \\
\hline
\end{tabular}

Tabel 6 menunjukkan bahwa sebanyak 28 (66,7\%) responden memiliki tradisi/kebiasaan yang kurang baik saat hamil dan14 (33,3\%) responden memiliki tradisi/kebiasaan yang baik saat hamil.

\section{4) Kepatuhan mengonsumsi tablet besi (Fe)}

Notoatmodjo memberi batasan pengertian tentang kepatuhan berasal dari kata patuh yang artinya suka, menurut, taat melaksanakan perbuatan sesuai aturan yang dianjurkan.Kepatuhan adalah tingkat perilaku seseorang dalam mengambil suatu tindakan dan kepentingannya ${ }^{5}$.

Kepatuhan konsumsi tablet besi (Fe) adalah meminum tablet Fe sesuai dengan dianjurkan. Distribusi responden menurut kepatuhan mengonsumsi tablet besi (Fe) pada ibu hamil disajikan pada tabel 7 .

Tabel 7. Distribusi responden berdasarkan kepatuhan mengonsumsi tablet besi ( $\mathrm{Fe}$ ) pada ibu hamil di wilayah kerja Puskesmas Waode Buri Kecamatan Kulisusu Utara Kabupaten Buton Utara tahun 2018

\begin{tabular}{ccc}
\hline Kepatuhan Mengonsumsi Fe & Jumlah $(\mathrm{n})$ & Persentase $(\%)$ \\
\hline Tidak Patuh & 28 & 66,70 \\
Patuh & 14 & 33,30 \\
\hline Total & 42 & 100
\end{tabular}

Tabel 7 menunjukkan bahwa sebagian besar atau sebanyak $28(66,7 \%)$ responden tidak patuh dalam mengonsumsi tablet besi (Fe) sedangkan 14 $(33,3 \%)$ responden termasuk patuh dalam mengonsumsi tablet besi (Fe) selama hamil. Hasil penelitian ini menunjukkan bahwa konsumsi tablet Fe pada ibu hamil di wilayah kerja Puskesmas Waode Buri Kecamatan Kulisusu Utara Kabupaten Buto Utara yang diperoleh sebagian besar berada pada kategori tidak patuh.

\section{b. Analisis Bivariat}

Analisis bivariat dilakukan dengan tujuan untuk melihat adanya hubungan antara faktor tradisi/kebiasaan dan tingkat pendidikan, dengan kepatuhan mengonsumsi tablet besi ( $\mathrm{Fe}$ ) pada ibu hamil.Uji statistik yang digunakan adalah Chi-Square yang disesuaikan dengan sifat data dan tujuan penelitian. Hasil analisis bivariat masing-masing variabel penelitian ini adalah sebagai berikut: 
1) Hubungan pekerjaan dengan kepatuhan mengonsumsi tablet besi (Fe) pada ibu hamil di wilayah kerja Puskesmas Waode Buri Kecamatan Kulisusu Utara Kabupaten Buton Utara tahun 2018
Hasil analisis hubungan karakter pekerjaan dengan kepatuhan mengonsumsi tablet besi (Fe) pada ibu hamil di wilayah kerja Puskesmas Waode Buri Kecamatan Kulisusu Utara Kabupaten Buton Utara disajikan pada tabel 8.

Tabel 8. Hubungan pekerjaan dengan kepatuhan mengonsumsi tablet besi (Fe) pada Ibu hamil di wilayah kerja Puskesmas Waode Buri Kecamatan Kulisusu Utara Kabupaten Buton Utara tahun 2018

\begin{tabular}{|c|c|c|c|c|c|c|c|c|}
\hline \multirow{3}{*}{ Pekerjaan } & \multicolumn{4}{|c|}{ Kepatuhan Mengonsumsi Tablet Besi (Fe) } & \multicolumn{2}{|c|}{ Jumlah (n) } & \multirow{3}{*}{$\begin{array}{c}P \\
\text { Value }\end{array}$} & \multirow{3}{*}{$\begin{array}{c}\text { Nilai } \\
\text { A }\end{array}$} \\
\hline & \multicolumn{2}{|c|}{ Tidak Patuh } & \multicolumn{2}{|c|}{ Patuh } & & & & \\
\hline & $\mathrm{N}$ & $\%$ & $\mathrm{~N}$ & $\%$ & $\mathrm{~N}$ & $\%$ & & \\
\hline Tidak bekerja & 11 & 68,75 & 5 & 31,25 & 16 & 100 & & \\
\hline Aktif bekerja & 17 & 65,38 & 9 & 34,61 & 26 & 100 & 0,023 & 0,05 \\
\hline Total & 28 & 66,7 & 14 & 33,3 & 42 & 100 & & \\
\hline
\end{tabular}

Berdasarkan tabel 8 menunjukkan bahwa sebanyak 16 responden dengan kategori aktif bekerja, sebanyak 11 (68,75\%) responden tidak patuh dalam mengonsumsi tablet besi (Fe) saat hamil dan sebanyak 5 (31,25\%) responden yang patuh dalam mengonsumsi tablet besi (Fe) saat hamil. Diantara 26responden dengan kategori aktif bekerja, terdapat 17 (65,38\%) responden yang tidak patuh mengonsumsi tablet Fe dan 9 (34,61\%) responden yang aktif bekerja dan patuh dalam mengonsumsi tablet besi saat hamil.

Hasil uji statistik dengan menggunakan uji Chi-Squqre diperoleh nilai $\mathrm{p}=0,023$ dan nilai $\alpha=$ 0,05 . Karena nilai $\rho(0,21)<$ nilai $\alpha(0,05)$ maka Ho ditolak, yang berarti bahwa ada hubungan yang signifikan antara faktor pekerjaan dengan kepatuhan mengonsumsi tablet besi (Fe) pada ibu hamil di wilayah kerja Puskesmas Waode Buri Kecamatan Kulisusu Utara Kabupaten Buton Utara.

Hasil penelitian ini sesuai dengan pendapat Maulida bahwa lingkungan pekerjaan dapat mempengaruhiseseorang memperoleh pengetahuan baik secara langsung maupun tidak langsung ${ }^{4}$ sehingga seseorang dapat dapat memperoleh informasi dan pengalaman. Penelitian ini juga sesuai dengan hasil penelitian yang pernah dilakukan olehFaiqohet al., yang menemukan adanya hubungan antara faktor pekerjaan ibu hamil dengan kepatuhan dalam mengonsumsi tablet $\mathrm{Fe}^{9}$. Hal ini dapat disebabkan karena orang dapat memperolah pengetahuan dari lingkungan tempatbekerja, sehingga muncul pemahaman yang baik dan motivasi yang baik.

Hubungan tingkat pendidikan dengan kepatuhan mengonsumsi tablet besi (Fe) pada ibu hamil di wilayah kerja Puskesmas Waode Buri Kecamatan Kulisusu Utara Kabupaten Buton Utara tahun 2018

Hasil analisis hubungan faktor pendidikan dengan kepatuhan mengonsumsi tablet besi (Fe) pada ibu hamil di wilayah kerja Puskesmas Waode Buri Kecamatan Kulisusu Utara Kabupaten Buton Utara disajikan pada tabel 9. 
Tabel 9. Hubungan tingkat pendidikan dengan kepatuhan mengonsumsi tablet besi (Fe) pada ibu hamil di wilayah kerja Puskesmas Waode Buri Kecamatan Kulisusu Utara Kabupaten Buton Utara tahun 2018

\begin{tabular}{|c|c|c|c|c|c|c|c|c|}
\hline \multirow{3}{*}{ Tingkat Pendidkan } & \multicolumn{4}{|c|}{ Kepatuhan Mengonsumsi Tablet Besi (Fe) } & \multicolumn{2}{|c|}{ Jumlah (n) } & \multirow{3}{*}{$\begin{array}{c}P \\
\text { value }\end{array}$} & \multirow{3}{*}{$\begin{array}{c}\text { Nilai } \\
\text { A }\end{array}$} \\
\hline & \multicolumn{2}{|c|}{ Tidak Patuh } & \multicolumn{2}{|c|}{ Patuh } & & & & \\
\hline & $\mathrm{n}$ & $\%$ & $\mathrm{n}$ & $\%$ & $\mathrm{n}$ & $\%$ & & \\
\hline Rendah & 14 & 93,3 & 1 & 6,7 & 15 & 100 & & \\
\hline Tinggi & 14 & 51,9 & 13 & 48,1 & 27 & 100 & 0,006 & 0,05 \\
\hline Total & 28 & 66,7 & 14 & 33,3 & 42 & 100 & & \\
\hline
\end{tabular}

Berdasarkan tabel 9 menunjukkan bahwa sebanyak 15 responden dengan kategori tingkat pendidikan yang rendah, terdapat 14 (93,3\%) responden tidak patuh dalam mengonsumsi tablet besi (Fe) saat hamil dan sebanyak 1 (6,7\%) responden patuh dalam patuh dalam mengonsumsi tablet besi (Fe) saat hamil. Diantara 27 responden dengan kategori tingkat pendidikan yang tinggi, terdapat 14 (51,9\%) responden yang tidak patuh mengonsumsi tablet Fe dan 13 (48,10\%) responden patuh dalam mengonsumsi Fe saat hamil.

Hasil uji statistik dengan menggunakan uji Chi-Squqre diperoleh nilai $p=0,006$ dan nilai $\alpha=$ 0,05 . Karena nilai $\rho(0,006)<$ nilai $\alpha(0,05)$ maka Ho ditolak, yang berarti bahwa ada hubungan yang signifikan antara faktor tingkat pendidikan dengan kepatuhan mengonsumsi tablet besi (Fe) pada ibu hamil di wilayah kerja Puskesmas Waode Buri Kecamatan Kulisusu Utara Kabupaten Buton Utara.

Secara teori tingkat pendidikan yang tinggi membuka atau menambah pengetahuan dari seseorang termasuk dalam hal manajemen pelayanan kesehatan.Artinya bahwa seseorang dengan pendidikan yang tinggi membuat seseorang menjadi berperilaku yang lebih baik seperti perilaku tidak merugikan oranglain serta perilaku mencari pelayanan kesehatan ketika sakit dan mengikuti tatalaksana pengobatan ${ }^{10}$.

Hasil analisis univariat dalam penelitian ini menunjukan sebagian besar yaitu sekitar 64,3\% responden memiliki tingkat pendidikan dengan kategori tinggi dan hanya 33,7\% responden dengan kategori pendidikan rendah dan pada analisis selanjutnya menunjukkan bahwa sebagian besar responden tidak patuh dalam mengonsumsi tablet besi (Fe). Hal ini bertentangan dengan teori pendidikan yang dikemukakan oleh Notoadmodjo ${ }^{10}$.Ini kemungkinan disebabkan oleh berbagai faktor misalnya faktor kurangnya informasi tentang pentingnya mengonsumsi tablet besi (Fe) dari petugas kesehatan. Faktor lain yang juga bisa menyebabkan responden yang sebagian besar memiliki tingkat pendidikan yang tinggi akan tetapi kurang patuh dalam mengonsumsi tablet besi adalah keyakinan masyarakat atau ibu hamil. Untuk diketahui bahwa masyarakat atau ibu hamil yang ada diwilayah kerja Puskesmas Waode Buri masih mempercayai obat-obatan dari dukun bayi.

Hasil uji statistik dengan menggunakan uji Chi-Squqre diperoleh nilai $p=0,006$ dan nilai $\alpha=$ 0,05 yang berarti bahwa ada hubungan yang signifikan antara faktor tingkat pendidikan dengan kepatuhan mengonsumsi tablet besi (Fe) pada ibu hamil di wilayah kerja Puskesmas Waode Buri Kecamatan Kulisusu Utara Kabupaten Buton Utara. Hasil penelitian ini didukung oleh penelitianMulyaniyang menemukan bahwa ada pengaruh antara tingkat pendidikan dengan K4 dengan nilai ${ }^{p}=0,0001^{12}$. Penelitian lain yang sejalan dengan penelitian ini adalah penelitian yang pernah dilakukan oleh Maulida yang menemukan bahwa ada hubungan antara faktor pendidikan dengan kepatuhan ibu hamil dalam mengonsumsi tablet besi (Fe) dengan nilai $p=0,001^{7}$. Hal ini memang karena pendidikan seseorang dapat membentuk perilaku posistif dari seseorang dalam merespon sebuah informasi kesehatan.

Hasil penelitian ini juga menunjukan bahwa sebagian besar tingkat pendidikan responden $(64,3 \%$.) tergolong dalam kategori pendidikan tinggi dan hanya $15(35,7 \%)$ responden memiliki pendidikan dengan kategori rendah. Situasi ini mestinya akan memudahkan dalam memberikan pemahaman kepada ibu hamil terkait pentingnya tablet Fe untuk dikonsumsi saat hamil. Akan tetapi faktor sumber informasi, motivasi serta jarak bahkan ketersediaan logistik Fe juga memiliki pengaruh terhadap kepatuhan ibu hamil dalam mengonsumsi Fe. 
Hubungan tradisi/kebiasaan dengan kepatuhan mengonsumsi tablet besi (Fe) pada ibu hamil di wilayah kerja Puskesmas Waode Buri Kecamatan Kulisusu Utara Kabupaten Buton Utara tahun 2018
Hasil analisis hubungan faktor taradisi atau kebiasaan dengan kepatuhan mengonsumsi tablet besi (Fe) pada ibu hamil di wilayah kerja Puskesmas Waode Buri Kecamatan Kulisusu Utara Kabupaten Buton Utara disajikan pada tabel 10.

Tabel 10.Hubungan tradisi/kebiasaan dengan kepatuhan mengonsumsi tablet besi (Fe) pada ibu hamil di wilayah kerja Puskesmas Waode Buri Kecamatan Kulisusu Utara Kabupaten Buton Utara tahun 2018

\begin{tabular}{|c|c|c|c|c|c|c|c|c|}
\hline \multirow{3}{*}{ Tradisi/kebiasaan } & \multicolumn{4}{|c|}{ Kepatuhan mengonsumsi tablet besi (Fe) } & \multirow{2}{*}{\multicolumn{2}{|c|}{ Jumlah (n) }} & \multirow{3}{*}{$\begin{array}{c}P \\
\text { Value }\end{array}$} & \multirow[t]{3}{*}{$\begin{array}{c}\text { Nilai } \\
\text { A }\end{array}$} \\
\hline & \multicolumn{2}{|c|}{ Tidak Patuh } & \multicolumn{2}{|c|}{ Patuh } & & & & \\
\hline & $\mathrm{n}$ & $\%$ & $\mathrm{n}$ & $\%$ & $\mathrm{n}$ & $\%$ & & \\
\hline Kurang & 21 & 75,0 & 5 & 35.7 & 26 & 100 & & \\
\hline Baik & 7 & 43.8 & 9 & 56.2 & 16 & 100 & 0.013 & 0,05 \\
\hline Total & 28 & 66,7 & 14 & 33,3 & 42 & 100 & & \\
\hline
\end{tabular}

Berdasarkan tabel 10 menunjukkanbahwa sebanyak 26 responden dengan kategori tradisi atau kebiasaan yang kurang baik, $21(75,0 \%)$ responden tidak patuh dalam mengonsumsi tablet besi (Fe) saat hamil dan sebanyak 5 (35,0\%) responden dengan tradisi/kebiasaan yang baik patuh dalam mengonsumsi tablet besi (Fe) saat hamil. Diantara 14 responden dengan kategori tradisi/kebiasaan yang baik, terdapat $5(35,7 \%)$ responden yang tidak patuh mengonsumsi tablet Fe dan 9 (64,7\%) responden yang memiliki tradisi/kebiasaan yang baik saat hamil tergolong patuh dalam mengonsumsi tablet besi saat hamil. Hasil uji statistik dengan menggunakan uji Chi-Square diperoleh nilai $p=0,004$ dan nilai $\alpha=0,05$. Karena nilai $\rho(0,013)<$ nilai $\alpha(0,05)$ maka Ho ditolak, yang berarti bahwa ada hubungan yang signifikan antara faktor tradisi/kebiasaan dengan kepatuhan mengonsumsi tablet besi (Fe) pada ibu hamil di wilayah kerja Puskesmas Waode Buri Kecamatan Kulisusu Utara Kabupaten Buton Utara.

Tradisi dalam arti yang sempit yaitu suatu warisan-warisan sosial khusus yang memenuhi syarat saja yakni yang tetap bertahan hidup di masa kini, yang masih tetap kuat ikatannya dengan kehidupan masa kini ${ }^{7}$.Tradisi dari sudut aspek benda materialnya adalah benda material yang menunjukkan dan mengingatkan hubungan khususnya dengan kehidupan masa lalu. Misalnya adalah candi, puing kuno, kereta kencana, beberapa benda-benda peninggalan lainnya, jelas termasuk ke dalam pengertian tradisi ${ }^{11}$.

Hasil penelitian ini dalam analisis univariat ditemukan bahwa dari 42responden sebagian besar $28(66,7 \%)$ memiliki tradisi atau kebiasaan yang tergolong kurang baik, terutama kebiasaan saat makan pada waktu hamil dan terdapat 14 (33,3\%) responden yang memiliki tradisi/kebiasaan yang tergolong baik pada saat hamil. Hal Ini menunjukkan bahwa betapa pentingnya faktor tradisi atau kebiasaan dalam lingkungan keluarga, terutama kebiasaan makan bagi ibu hamil, termasuk untuk menentukan pengambilan sikap dalam mengikuti program pelayanan kesehatan seperti kepatuhan mengonsumsi tablet besi $(\mathrm{Fe})^{12}$.Seperti halnya dengan penelitian Erdila yang menemukan bahwa sebagian besar yaitu $84,5 \%$ responden ibu hamil yang diteliti memiliki budaya melakukan pemeriksaan kehamilan secara lengkap dan mengikuti perawatan kehamilan dengan baik termasuk dalam mengonsumsi tablet Fe adalah mereka yang memiliki kebiasaan yang baik pada saat menjalani kehamilan $^{13}$.

\section{SIMPULAN DAN SARAN}

Berdasarkan hasil analisis yang dilakukan dalam penelitian ini dapat disimpulkan bahwa faktor karakteristik individu yaitu pekerjaan dan pendidikan 
serta dan faktor tradisi/budaya merupakan faktor yang mempengaruhi kepatuhan konsumsi tablet Fe pada ibu hamil. Namun demikian, peneliti meyakini bahwa banyak faktor yang merupakan prediktor dalam kepatuhan ibu hamil dalam mengonsumsi tablet $\mathrm{Fe}$, sehingga saran kepada peneliti selanjutnya adalah perlu dilakukan penelitian terhadapfaktor-faktor lain yang ikut mempengaruhi kepatuhan ibu hamil dalam mengonsumsi tablet Fe.

\section{DAFTAR PUSTAKA}

1. Almatsier, S. (2010). Prinsip dasar ilmu gizi. Jakarta: Gramedia Pustaka Utama.

2. Waryana. (2010). Gizi reproduksi. Yogyakarta: Pustaka Rihama.

3. WHO. (2017). World Health Statistic 2017: Monitoring Health for SDg"s. Available from: www.who.int/gho/.../world health stati stics/2017/en/Diakses tanggal 27 Juli 2018.

4. Annisa Annisa. 2016. Faktor - Faktor yang Mempengaruhi Pemanfatan Antenatal Care di Wilayah Kerja Puskesmas Mokoau Kec. Kambu Kota Kendari Tahun 2016. Skripsi FKM Universitas Halu Oleo.

5. Dinkes Kab. Buton Utara. (2018). Profil Dinas Kesehatan Kabupaten Buton Utara Tanhun 2017.

6. Maulida, N.S. (2013). Hubungan tingkat pengetahuan anemia pada ibu hamil dengan kepatuhan mengonsumsi tablet besi (Fe) di Puskesmas Keling II Kabupaten Jepara tahun 2013.

7. Dinkes Provinsi Sultra (2018). Profil Dinas Kesehatan Provinsi Sulawesi Tenggara Tahun 2017.

8. Notoatmodjo. (2005). Metodologi penelitian kesehatan. Jakarta: Rineka Cipta.

9. Faiqoh, Uswatul, K.L \& Sukmawati. (2014). Hubungan karakteristik ibu, ANC dan kepatuhan perawatan ibu hamil dengan terjadinya preeklampsia. Media Kesehatan Masyarakat Indonesia. 2(2): 216-226.

10. Saefullah, A. (2007). Tradisi sompa, studi tentang pandangan hidup masyarakat Wajo di tengah perubahan sosial. Unpublished undergraduate thesis. Universitas Islam Negeri Malang.
11. Notoatmodjo. (2011). Kesehatan masyarakat ilmu \& seni. Jakarata: Rineka Cipta.

12. Mulyani, Y.S. (2016). Pengaruh pendidikan kesehatan terhadap pengetahuan ibu hamil usia gestasi 36 40 minggu tentang cara menyusui di wilayah Puskesmas Pisangan. Available From:repository.uinjkt.ac.id/dspace/.../1/ YULI\%20SRI\%20MULYANI\%20\%20FKIK.pdf

13. Erdila, M. (2013). Budaya kehamilan dan persalinan. Available from:(http://mitaerdila.wordpress.com/2 013/01/06/budaya-kehamilan-danpersalinan/). Diakses tanggal 20 Juni 2018. 